\title{
DEVELOPMENT OF SINKHOLES IN A THICKLY COVERED KARST TERRANE
}

\author{
Sam B. Upchurch, Thomas L. Dobecki, Thomas M. Scott, Steven H. Meiggs, \\ Sarah E. Fratesi, Michael C. Alfieri \\ SDII Global Corporation, 4509 George Road, Tampa, Florida, 33634, USA, supchurch@sdii-global.com
}

\begin{abstract}
A cluster of aquifer drawdown-induced sinkholes developed in eastern Hillsborough County, Florida (west-central Florida), during two major freeze events in 2010. The sinkholes resulted in millions of dollars in losses and caused us to revise our thinking about how sinkholes form in a terrain normally considered to have low sinkhole risk owing to thick, clay-rich cover.
\end{abstract}

The cover material consists of the Miocene Hawthorn Group, which includes up to $120 \mathrm{~m}$ of interfingering expansive clay, sand and sandy clay, and carbonate strata. The lower Hawthorn Group Arcadia Formation is primarily carbonate and is up to $90 \mathrm{~m}$ thick. The upper Hawthorn Group Peace River Formation contains more clay and sand with minor amounts of carbonate and is up to $30 \mathrm{~m}$ thick. The Hawthorn Group constitutes an effective aquitard for the underlying upper Floridan aquifer (UFA), which is composed of karstic, Oligocene and Eocene limestone and dolostone.

A rapid drawdown of up to $20 \mathrm{~m}$ in the potentiometric surface of the underlying UFA resulted in mobilization of water-saturated clays and clayey sands within the Hawthorn Group. Subsidence and possible clay consolidation resulting from dewatering and loss of support/buoyancy caused development of new sinkholes and reactivation of clay-filled sinkholes that had developed as early as the Miocene Epoch. Stable, clay-filled, relict sinkholes of apparent Miocene age discovered in an earlier investigation in the same area in 1998-1999 support the presence of clay-filled, relict sinkholes in the area. Combining information gathered from study of these modern and relict sinkholes presents evidence of sinkhole development mechanisms in the thickly covered karst of west-central Florida.

\section{Introduction}

This paper synthesizes evidence from three karst investigations suggesting that migration or consolidation of water-saturated, expansive clay under severe, short- duration hydraulic head stresses can result in rapid sinkhole development.

The three investigations relate to sinkhole activity in different stages of development, but with apparently similar origins. From these three investigations, a case can be made for (1) rapid dewatering and consolidation or (2) movement of near-liquid, clay-rich sediments under hydraulic stress into voids in the adjacent limestone to form sinkholes.

\section{The Three Investigations}

The three investigations are discussed below in chronological order of occurrence.

\section{Tampa Bay Regional Reservoir Investigation}

In 1999, we completed site characterization for construction of an above-grade, 445 ha reservoir in southeastern Hillsborough County, Florida (Figure 1; Upchurch et al. 1999; Dobecki and Upchurch 2010). The site is located on the Polk Upland Physiographic Province (White 1970) and is underlain by a thick (up to $120 \mathrm{~m}$ ) sequence of clay, sand, and limestone and dolostone of the Peace River and Arcadia Formations of the Miocene Hawthorn Group (Scott 1988; Arthur et al. 2008). The Miocene strata form an effective aquitard for the underlying limestone of the upper Floridan aquifer (UFA).

Three deep (>30 m) sinkhole-related features were discovered as part of the reservoir investigation (Figure 2). The reservoir embankment footprint was altered to avoid one feature that was of concern because of loose sediments in the subsurface; the second feature was a sand-filled, relict sinkhole that, based on the fill material, was determined to be contemporary with Plio-Pleistocene marine sedimentation; and the third feature (arrow, Figure 2) was filled with the green, sandy clay typical of the Miocene of Florida. This third, relict sinkhole apparently formed and was filled at the time of development of the Miocene/Pliocene unconformity. 


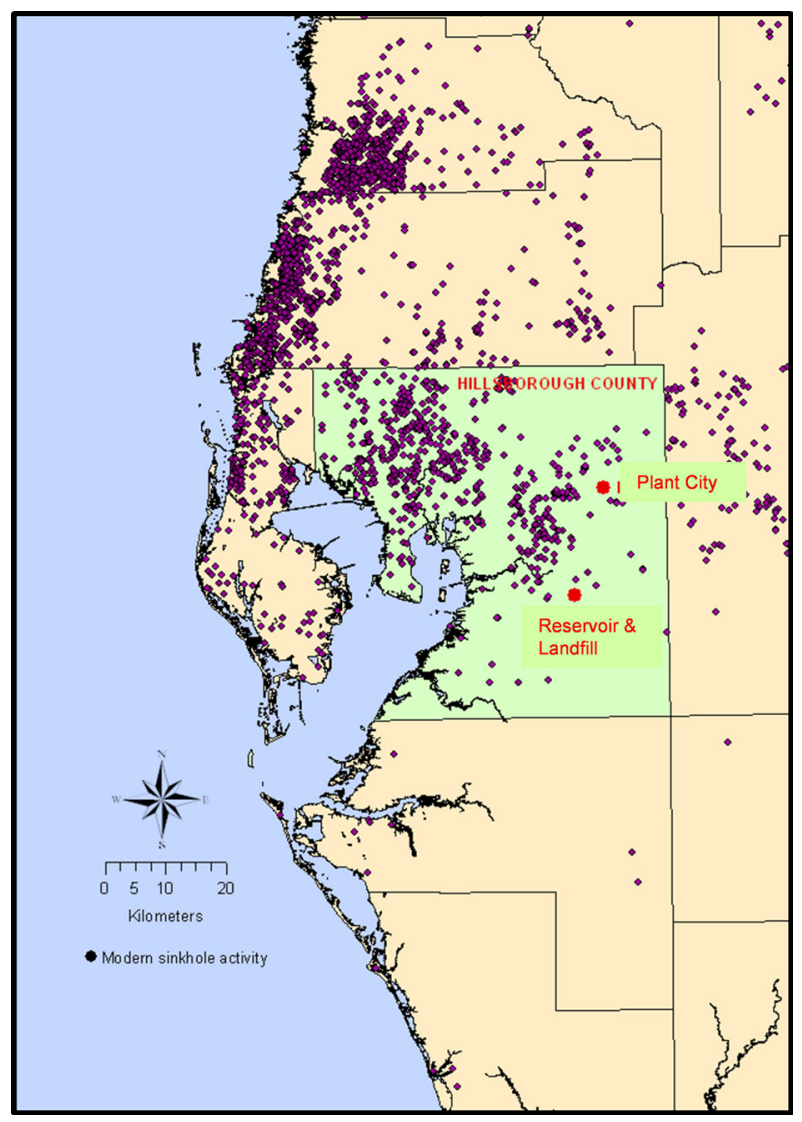

Figure 1. The Tampa Bay area of west-central Florida. Locations of the three investigations are shown in red, and known sinkholes that have formed since 1984 are shown in violet.
The latter two features were geotechnically stable and have been subjected to 10 years of reservoir management and seasonal cycling of hydraulic heads. Groundwater levels at the reservoir are regularly monitored and it is clear that these relict sinkholes are isolated and stable. The latter two features are deemed to be safe for impounding water within the reservoir because they do not react to sudden stresses caused by drawdown in the underlying Floridan aquifer or to changes in reservoir stage.

This is not the case for the two case studies that are described below.

\section{The Plant City Sinkhole Cluster Investigation}

In January 2010 a hard freeze with overnight temperatures below $0^{\circ} \mathrm{C}$ that lasted eleven days near Plant City (Figure 1) in eastern Hillsborough County resulted in heavy groundwater withdrawals from the confined UFA for irrigation to protect crops from freezing. The potentiometric surface of the UFA declined up to $18 \mathrm{~m}$, with up to $9 \mathrm{~m}$ daily excursions in potentials. As a result, at least 132 sinkholes developed within the overlying Hawthorn Group sediments within seven days of the event (Figures 3, 4).

Testing of many of these sinkholes by the authors revealed a persistent pattern: there was a thick (up to

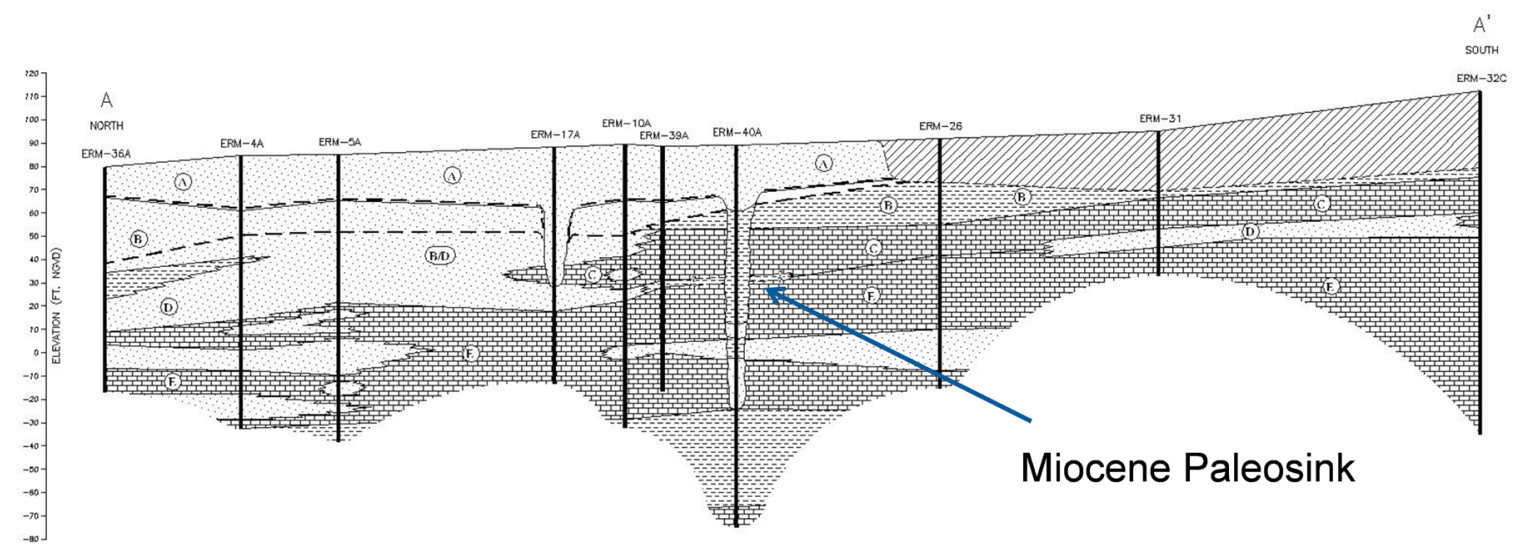

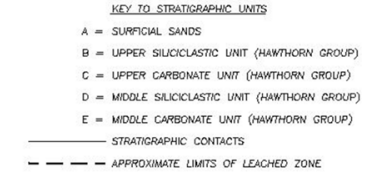

- - - - APPROXMATE LMTSS OF LEACHEO ZONE

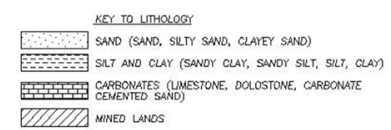

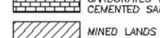

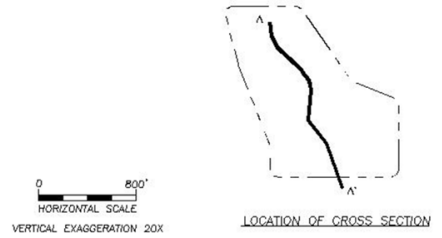

Figure 2. North-south cross section through the reservoir to illustrate the locations and stratigraphic context of the Polk Upland sinkholes. Source: Dobecki and Upchurch 2010. 
$30 \mathrm{~m}$ ) layer of expansive, smectitic clay with natural moisture contents that were at or near the liquid limits of the clays. Under standard penetration (SPT) testing, these clays had weight-of-rod or -hammer strengths (Table 1). Owing to the high clay content of the nearsurface sediments, there was little evidence of suffosion; rather, many of the subsidence features reflected vertical collapse of intact, cylinder-like volumes of sediment resulting in sinkhole depths of up to $5 \mathrm{~m}$ and diameters of up to $50 \mathrm{~m}$ (Figures 3, 4).

\section{The Southeast Hillsborough Landfill Investigation}

In December 2010 there was a second, but less severe, episode of rapid drawdown of the UFA as a result of pumping for freeze protection. Shortly after this event a $45 \mathrm{~m}$ wide and nearly $60 \mathrm{~m}$ deep sinkhole (Figure 5) developed on the edge of a major Class I landfill about 3 $\mathrm{km}$ south of the reservoir site.

The landfill sinkhole developed in a section of mixed sand, clay and limestone strata (Figure 6). The unique feature of this sinkhole is that there is no evidence of a significant breakdown or collapse debris mound at the bottom of the aven.

It appears that the sinkhole developed over pre-existing void space where the materials had been removed from the stratigraphic column to form the aven and a bell-shaped void at the base of the aven (Figure 6). The sediments in this larger void space had also been previously removed. While the waste mass or the shallow limestone bed (Figure 6) may have bridged the void, a mechanism was required for the removal of the missing siliciclastic sediment. Refusal strength ( $\mathrm{N}>50$ blows/foot of SPT penetration) sand and sandy clay

Table 1. Sample results from a standard penetration test boring adjacent to a sinkhole in Plant City.

\begin{tabular}{|l|c|}
\hline Lithology & N Values* \\
\hline 0-8 m - Sand and sand with silt & $16-49$ \\
\hline $\begin{array}{c}\text { 8-32 m - Clay with minor clayey sand; } \\
\text { expansive (LL = 104\%, PI = 42\%); } \\
\text { clayey sand seams were approx. 1.5 } \\
\text { m thick }\end{array}$ & $\begin{array}{c}0-29 \\
\text { (weight-of- } \\
\text { rod- or ham- } \\
\text { mer- strength } \\
\text { clay for 5.5 } \\
\mathrm{m} \text { ) }\end{array}$ \\
\hline $\begin{array}{c}\text { 29-36 m (end of boring) - Limestone with } \\
\text { chert }\end{array}$ & $72-100+$ \\
\hline
\end{tabular}

*Blows/ft. penetration

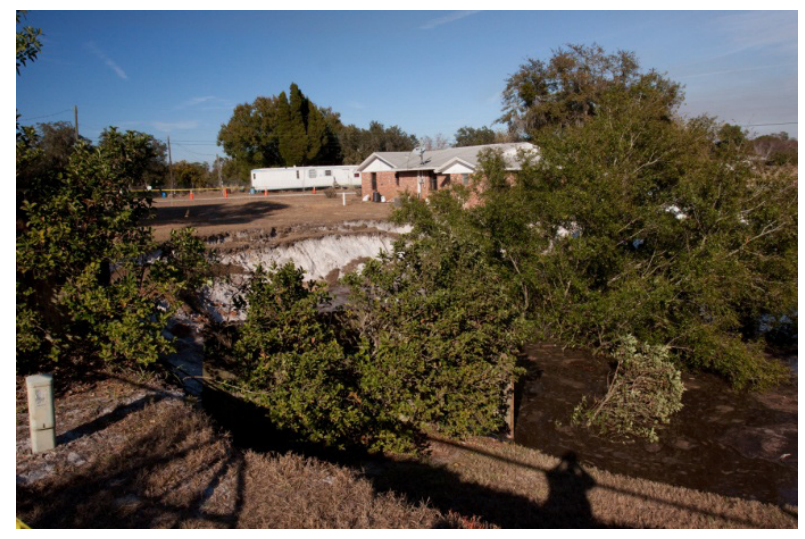

Figure 3. A large sinkhole that developed by vertical movement near Frostproof, Florida. Note the intact trees in the down-thrown sediment "plug."

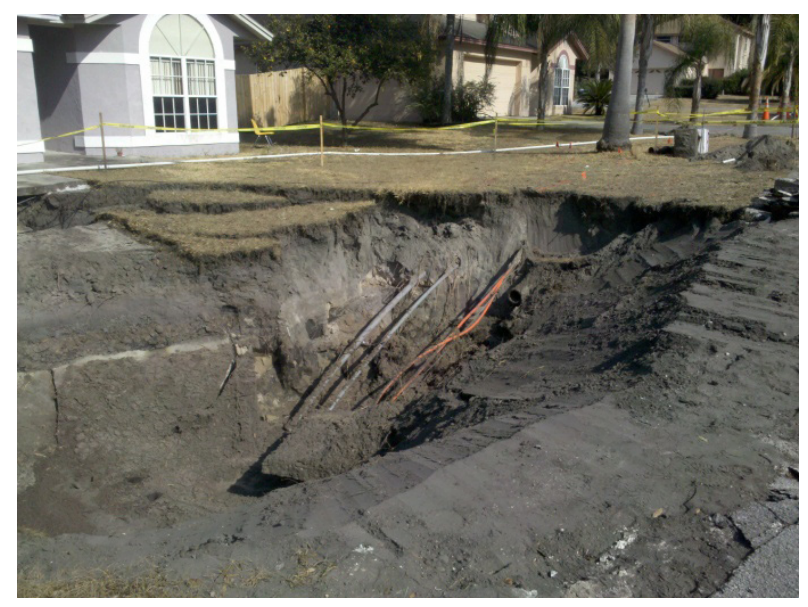

Figure 4. Sinkhole that developed in a suburb of Plant City. This was one of seven on the street. Sand has been placed in the foreground to reduce risk of additional damage to the street.

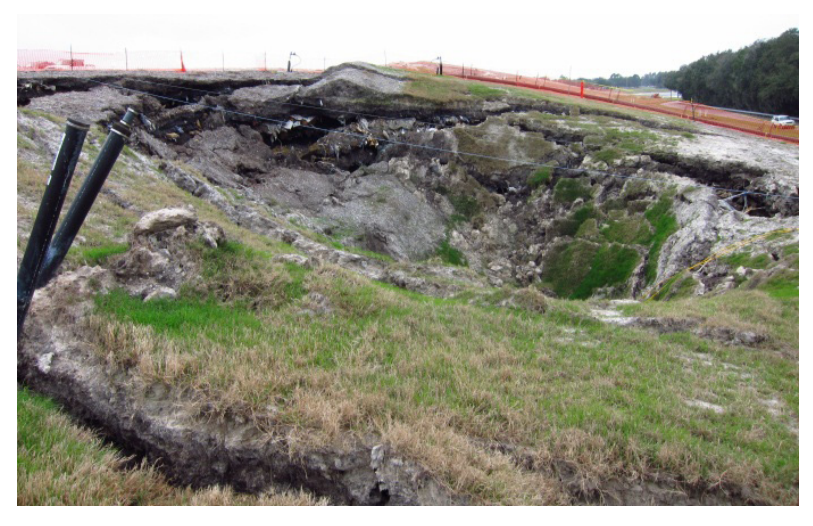

Figure 5. The landfill sinkhole in southeastern Hillsborough County, Florida. Note the slump features developed within the waste mass. 


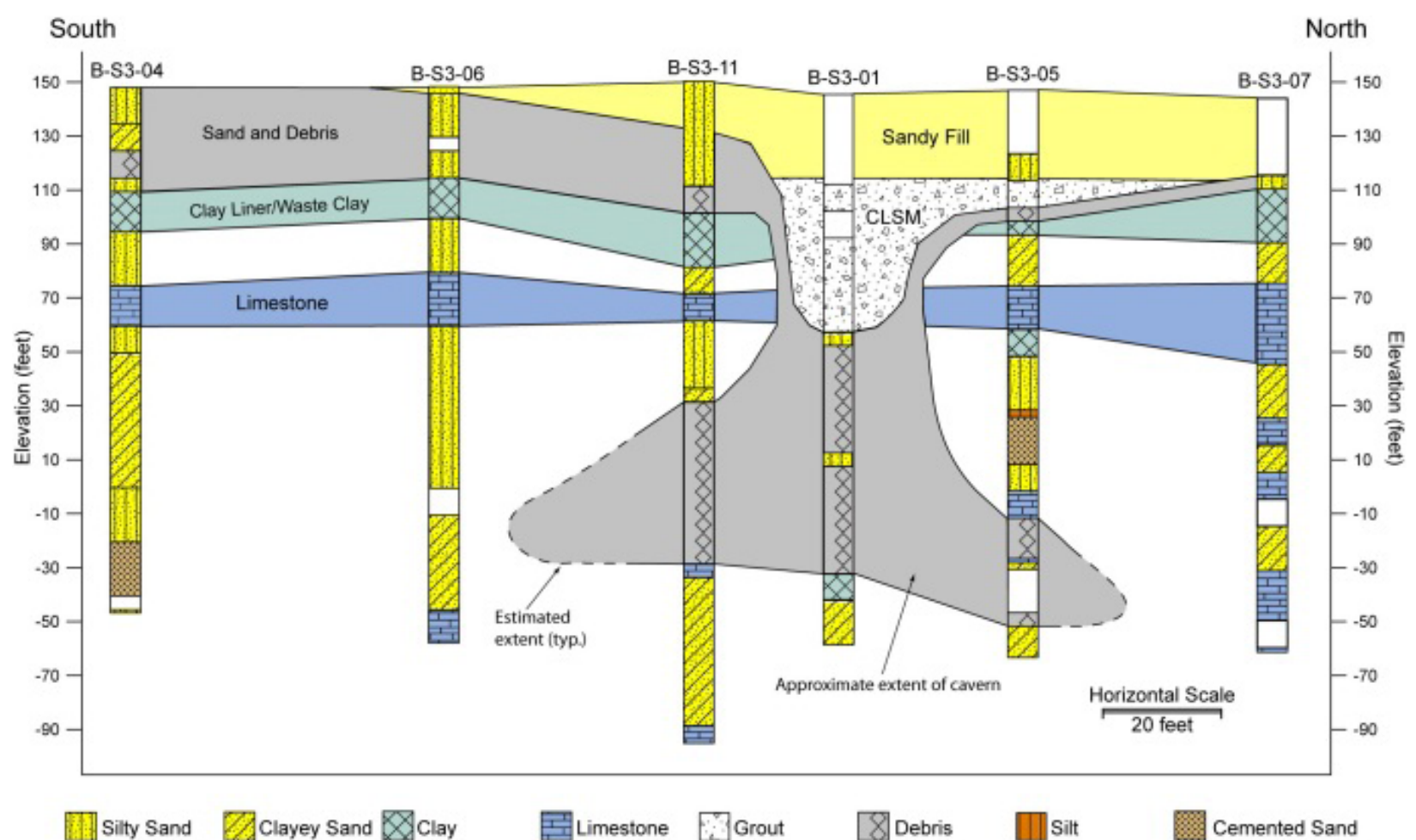

Figure 6. North-south cross section of the landfill sinkhole. (Note that depths are presented in feet and that the cross section was developed from standard penetration testing after initial stabilization of the sinkhole and backfilling to allow safe access for testing. CLSM is cementitious Controlled Low Strength Material used to cap the aven and stabilize the site) Source: on-going investigation by the authors.

surrounds most of the void. As such, the walls of the aven and bottom void are well supported. However, the perplexing question is: where did the collapse material go?

It appears that the sediments that occupied the void space had been washed out of the space at some earlier time, perhaps during the freeze event in January 2010 or even earlier. This would explain the absence of breakdown debris at the bottom of the void. The void, therefore, was either bridged over by the upper limestone, which was not detected as rubble at the base of the void, or perhaps the waste mass itself.

\section{Interpretation, Conclusions, and Epilogue}

Based on comparisons of the results from the three investigation areas, we suggest that the Polk Upland sinkholes developed as follows (Figure 7):

1. The Polk Uplands are underlain by the Miocene Hawthorn Group. The Hawthorn Group includes clay, sand, and carbonate units (Figures 2 and 6). These strata form an effective aquitard that confines the underlying UFA. When extremely heavy withdrawals of groundwater from the UFA occur, lack of concomitant leakage from overlying water sources (surficial aquifer, surficial water bodies, localized aquifers within the confining unit) causes sharp, short-term declines in the potentiometric surface.

2. Karst features, including sinkholes, began to develop in the Hawthorn Group near the end of Miocene time (the post-Hawthorn unconformity; Scott 1988). Some sinkholes were filled with Miocene clay and others with younger Plio-Pliocene marine sands. The features thought to have formed this way at the reservoir contain strong, well-consolidated sediments that appear unaffected by modern hydraulic stresses.

3. Elsewhere, some of these features appear to have been filled with clay and clayey sand that has not been well consolidated, resulting in localized 


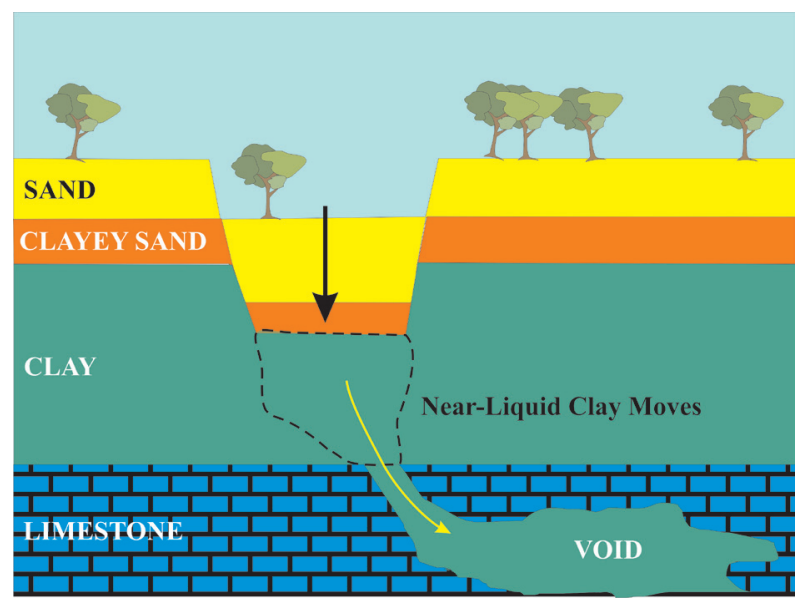

Figure 7. Potential mode of sinkhole formation within the clay-rich strata of the Hawthorn Group on the Polk Uplands of Florida.

pockets of soft clay with natural moisture contents near or exceeding their liquid limits.

4. When sudden and short-term, deep declines caused by groundwater withdrawals occur in the potentiometric surface of the UFA, some of these under-consolidated clay and clayey sand deposits may fail, either by simple dewatering and rapid consolidation or by migration of the clay and associated sandy sediments into the voids of the subjacent limestone (Figure 7).

As shown in Figure 7, our current concept as to how these sinkholes form is by migration of clay and clayey sand into void space in adjacent Hawthorn Group limestone or the underlying Oligocene and Eocene limestone of the UFA. The fluid nature of the saturated, expansive clays and clayey sands allow them to migrate farther laterally than might be otherwise expected into void space not directly beneath the sinkhole. This migration explains why there was no evidence of breakdown or collapse materials, other than landfill waste, on the floor of the Southeast Hillsborough Landfill sinkhole.

Clay and clayey sand remain under the sinkholes we tested near Plant City. In this case, either the clay and clayey sand were simply dewatered and consolidated or migration into nearby void space was incomplete. While this clay and clayey sand sediment is poorly consolidated, water-saturated, and near its liquid limit, sudden migration of water out of the clay mass would be hindered by the low intrinsic permeability of the material. Therefore, partial physical migration of the near-liquid clay seems the better hypothesis, a process that links these sinkholes genetically with the Southeast Hillsborough Landfill sinkhole.

The Polk Uplands remain a low sinkhole probability area, but when sinkholes develop they can be locally common, large, and catastrophic. The ones we investigated appear to have been triggered by significant, short-term hydraulic gradients caused by groundwater withdrawals from the highly confined UFA.

The local water-use permitting agency, the Southwest Florida Water Management District, has taken steps to minimize future major drawdown events by declaring a water caution area and adopting additional regulations related to water use and sources.

\section{References}

Arthur JD, Fischler C, Kromhout C, Clayton JM, Kelley, GM, Lee RA, Li L, O'Sullivan M, Green RC, and Werner CL. 2008. Hydrogeologic framework of the Southwest Florida Water Management District. Tallahassee: Florida Geological Survey, Bulletin 66,102 p. 59 plates.

Dobecki TL, Upchurch SB 2010. A multi-level approach to site characterization - C.W. Bill Young Regional Reservoir, Hillsborough County, Florida. Proceedings, 23rd Symposium on the Application of Geophysics to Engineering and Environmental Problems, p. 508-516.

Scott TM. 1988. The lithostratigraphy of the Hawthorn Group (Miocene) of Florida. Tallahassee: Florida Geological Survey, Bulletin 59, 148 p.

Upchurch SB, Dobecki TL, Daigle DM. 1999. Geological, hydrogeological, and geophysical investigation. In: Law Engineering Services and others, Geotechnical Site Characterization Report - Tampa Bay Regional Reservoir. Vol. I, Sec3, 76 p. plus figures and tables.

White WA. 1970. The geomorphology of the Florida Peninsula. Tallahassee: Florida Bureau of Geology, Geological Bulletin 51, 164 p. 
